\title{
Organic acids induce by metal-tolerant Pantoea sp. WP-5 and biogas residues enhanced phytostabilization of cadmium in soil
}

\section{Muhammad Tahir}

COMSATS University Islamabad - Vehari Campus

\section{Muhammad Bismillah Khan}

Bahauddin Zakariya University

\section{Muhammad Shahid}

government College University Faisalabad

Iftikhar Ahmad ( $\square$ iffises@yahoo.com )

COMSATS University Islamabad-Vehari Campus https://orcid.org/0000-0001-8811-1247

\section{Umaira Khalid}

Bahauddin Zakariya University

\section{Muhammad Akram}

COMSATS University

\section{Ahmad Dawood}

COMSATS University Islamabad

\section{Muhammad Kamran}

COMSATS University Islamabad

\section{Research Article}

Keywords: antioxidants, growth, heavy metals, indole-3-acetic acid, root exudates

Posted Date: March 19th, 2021

DOl: https://doi.org/10.21203/rs.3.rs-252877/v1

License: (1) (1) This work is licensed under a Creative Commons Attribution 4.0 International License. Read Full License 


\section{Abstract}

This study investigated the phytoremediation potential of maize (Zea mays L.) in Cd contaminated soil through co-inoculation of metal tolerant plant beneficial rhzobacteria (MtPBR: Pantoea sp. strain WP-5) with organic manures (PM: poultry manure and BGR: biogas residues). The objectives of this study were to i) examine comparative efficiency of MtPBR, PM and BGR alone or in combined form to improve maize biomass and physiology, and ii) understand the role of organic acid production in root exudates of maize for $\mathrm{Cd}$ accumulation and translocation. Pantoea sp. WP-5 showed tolerance to high $\mathrm{Cd}$ concentration $\left(1000 \mathrm{mg} \mathrm{L}^{-1}\right)$, thereby inoculated to maize seeds sown in soil spiked with $75 \mathrm{mg} \mathrm{Cd} \mathrm{kg}^{-1}$ soil and $500 \mathrm{~g}$ each of the organic manures per pot. The co-inoculation of MtPBR + BGR significantly $(P<0.05)$ increased chlorophyll contents, root/shoot dry weight, photosynthetic rate, stomatal conductance and relative water contents, whereas decreased electrolyte leakage, malondialdehyde contents, ascorbate peroxidase and catalase activity in maize over the control treatment. The co-inoculation of MtPBR + BGR produced significantly $(P<0.05)$ higher concentrations of acetic and citric acid $(52.7 \pm 0.5$ and $22.8 \pm 0.08$ $\mu \mathrm{g} \mathrm{g}^{-1}$ root fwt, respectively) in root exudates of maize, which immobilized Cd within plant roots inferred by the positive relation (root $\mathrm{Cd}$ vs. organic acids; $\mathrm{R}^{2}=0.80-0.92$ ) and reduced $\mathrm{Cd}$ translocation to shoots inferred by the negative relation (shoot $C d$ vs. organic acids; $R^{2}=0.81-0.90$ ). It is concluded that the application of MtPBR + BGR enhanced organic acid induced phyto-stabilization and accumulation of Cd in roots and restricted its translocation to shoots.

\section{Introduction}

Soil, the only growth medium for arable crops, is now becoming useless due to deposition of heavy metals. Heavy metals (HMs) like cadmium (Cd), chromium ( $\mathrm{Cr}$ ), nickel ( $\mathrm{Ni})$, lead (Pb), arsenic (As), zinc (Zn) and copper (Co) are frequently found in agricultural soils (Ahmad et al., 2020). The HMs are known to produce reactive oxygen species (ROS), stimulate/inhibit antioxidant enzyme production, exert oxidative damage to plants, damage cell organelles and sometime cell death occurs (Georgiadou et al., 2018; Berni et al., 2019). Moreover, the functioning of enzymes is retarded due to formation of bond between HMs and sulfhydryl groups of the enzymes (Most and Papenbrock, 2015; Sethi and Gupta, 2015).

Cd is present in soil (0.1-0.2 $\left.\mathrm{mg} \mathrm{kg}^{-1}\right)$ and is lethal metal to living system which include plants, animals, and humans. This poisonous HM is released into the soil through number of anthropogenic activities which include mining, fertilizer and batteries production and wastewater application (Ahmad et al., 2020), and caused contamination of soil with Cd (Latif et al., 2020). Soil contamination with Cd is a major threat to agriculture, as it has negative effects on plant biomass and physiology (Ahmad et al., 2020). Plants take up Cd from soil at fast rate and transport it to leaves through xylem tissues (Pirselova et al., 2011; Rizwan et al., 2016). Cd stress causes reduction in $\mathrm{CO}_{2}$ conductance, which lead to overall photosynthesis inhibition (Anjum et al., 2016). Physio-chemical and biological techniques are used to 
remediate heavy metal contaminated soils; however, phytoremediation is an effective technique (Hasan et al., 2019).

Maize (Zea mayz L.) due to its better Cd accumulation capacity and high biomass production potential has been widely used as probable candidate for management of $\mathrm{Cd}$ - contaminated soils (Rizwan et al., 2016). Maize is resistant to moderate level of Cd stress in soil. However, seed germination, mineral nutrition, photosynthesis, and growth/yields of maize may be reduced due to higher level of $\mathrm{Cd}$ contamination in soil (Ahmad et al., 2020). Role of root morphology and root functions in maize Cd uptake is imperative (Bi et al., 2009; Rizwan et al., 2016) as the most of the Cd entry in maize through apical parts of the roots has been reported as compared to root basal parts (Lux et al., 2015). After absorption by the root, large proportion of the $\mathrm{Cd}$ is fixed in the roots while only a small amount of the $\mathrm{Cd}$ is translocated to shoot (Puertas-Mejia et al., 2010; Ahmad et al., 2014, 2020). Due to this reason, maize can be used as potential candidate in the phytoremediation of low-to moderately-Cd-contaminated soils (Xu et al., 2013).

Organic amendments which include use of plant beneficial rhizobacteria (PBR), manures like compost, farm yard manure (FYM), poultry manure (PM) and biogas residues (BGR) not only help in improving plant growth but also regulate the rhizosphere bioremediation of metals through improving rhizoextraction and rhizo-immobilization processes (Khurana and Kansal 2014; Shumba et al., 2014; Ahmad et al., 2015, 2018). Application of BGR and compost has increased maize tolerance to $\mathrm{Cd}$ and improved the growth and biomass yield of maize in Cd contaminated soil (Ahmad et al., 2015). Use of some chemicals like EDTA, nitrilotriacetic acid, citric and oxalic acid as well as organic amendments have a significant role in bio- or phyto-remediation of heavy metals (Xu et al., 2013; Shahid et al., 2014; Ahmad et al., 2015; 2018; Hasan et al., 2019). Functional group $\left(\mathrm{COOH}^{-}\right.$as well as $\left.\mathrm{OH}^{-}\right)$of the organic acids make a complex with metals like $\mathrm{Cd}^{+2}$ and restrict its translocation (Xu et al., 2013; Hasan et al., 2019; Bali et al., 2020), in contrast, Chen et al. (2020) found higher accumulation of Cd in sorghum grass in the presence of citric acid and maltose. However, studies on the inoculation of organic acid producing bacteria to maize and their effect on root exudates under $\mathrm{Cd}$ stress is remain elusive. Production of organic acids like acetic acid, oxalic as well as citric acid by the plant beneficial rhizobacteria and the role of these acids in $\mathrm{P}$ solubilization has been reported in our previous studies (Tahir et al., 2013, 2015). We hypothesized that use of the organic acid producing MtPBR along with organic treatments such as BGR and PM enhance the phytoextraction and bioaccumulation of $\mathrm{Cd}$ in Zea mays L. under Cd contaminated soil. The objectives of this study were to i) examine comparative efficiency of PBR, PM and BGR alone or in combined form to improve maize biomass and physiology and ii) understand the role of organic acid production in the root exudates of maize for $\mathrm{Cd}$ accumulation and translocation.

\section{Materials And Methods}

\subsection{Source of PBR, PM and BGR}


Plant beneficial bacterial strain Pantoea sp. WP-5 (accession no. HE661627; Tahir et al., 2015) obtained from NIBGE Biotech Resource Centre. Recently this strain was characterized positive for IAA, produced organic acids and solubilized $P$ in culture medium (Tahir et al., 2020). The organic manures such as PM and BGR collected from local industry were characterized for nutritional status using the standard procedures. The PM contains $2.13 \% \mathrm{~N}, 1.91 \% \mathrm{P}$ and $1.52 \% \mathrm{~K}$, while the BGR contains $1.71 \% \mathrm{~N}, 0.96 \% \mathrm{P}$, $1.26 \% \mathrm{~K}$.

\subsection{Cd tolerance measurement of PBR}

The plant beneficial bacterial strain Pantoea sp. WP- 5 was tested for $\mathrm{Cd}$ tolerance through measuring the minimum inhibitory concentration (MIC) of $\mathrm{Cd}$. The strain was grown in nutrient-agar medium amended with $0-2000 \mathrm{mg} \mathrm{L}^{-1} \mathrm{Cd}$ using $\mathrm{CdCl}_{2}$ as salt. MIC for the $\mathrm{Cd}$ was calculated by observing the growth of the strain after 7 days of incubation at $28 \pm 2{ }^{\circ} \mathrm{C}$. The minimum concentration on which the growth of the strain Panotea sp. WP-5 was inhibited, considered as MIC.

\subsection{Pot experiment}

A pot experiment was carried out at Agriculture research farm of Bahauddin Zakariya University Multan $\left(30^{\circ} 11^{\prime} 52^{\prime \prime} \mathrm{N} 71^{\circ} 28^{\prime} 11^{\prime \prime} \mathrm{E}\right)$, Pakistan. For this purpose, soil was collected from an experimental field of the Agriculture research farm of Bahauddin Zakariya University Multan from the depth of 0-15 cm using auger. The soil was dried up in air, minced and sieved through a $2 \mathrm{~mm}$ sieve. A composite soil sample before pot experimentation was examined for physico-chemical characteristics (saturation percentage, total nitrogen, organic matter, soil texture, available phosphorus, extractable potassium, total Cd, electrical conductivity and $\mathrm{pH}$ ) by following standard analytical methods as mentioned in ICARDA manual. The proportion of sand, silt and clay in the soil was $25.6 \%, 53.1 \%$ and $18.4 \%$ respectively. The $\mathrm{pH}$, saturation percentage (SP) and electrical conductivity (EC) values were estimated as $8.2,30 \%$, and $3.41 \mathrm{dS} \mathrm{m}^{-1}$, respectively. The organic matter (OM), total $\mathrm{N}$, available $\mathrm{P}$, extractable $\mathrm{K}$ and $\mathrm{Cd}$ contents values were measured as $0.6 \%, 0.04 \mathrm{mg} \mathrm{kg}^{-1}, 6.2 \mathrm{mg} \mathrm{kg}^{-1}, 198 \mathrm{mg} \mathrm{kg}^{-1}$ and $0.2 \mathrm{mg} \mathrm{kg}^{-1}$, respectively.

The homogenized soil $(10 \mathrm{~kg})$ was filled in earthen pots of area $0.035 \mathrm{~m}^{2}$. The soil was spiked with 75 $\mathrm{mg} \mathrm{Cd} \mathrm{kg}{ }^{-1}$ soil using $\mathrm{CdCl}_{2}$ as salt five days prior to start of the experiment. After five days of spiking, all the treatments (PBR, PM, BGR, PBR+PM, PBR+BGR, PM+BGR, PBR+PM+BGR) along with control without PBR, BGR and PM) were applied in Cd contaminated (75 mg Cd kg-1 soil) and normal soil. The manures PM and BGR were applied @ of $0.5 \mathrm{~kg} /$ pot. To inoculate the PBR strain (Pantoea sp. WP-5), the seeds of maize hybrid ICl-9091 (obtained from Ayyub Agriculture Research institute, Faisalabad) were mixed with mixture of over-night grown bacterial culture of Pantoea sp. WP- 5 with strength of $10^{9}$ colony forming units (cfu) per $\mathrm{mL}$ and the sugar cane filter mud (at the rate of $0.5 \mathrm{~g}$ per $100 \mathrm{~g}$ seed). The seeds (10 seeds per pot) were sown in the earthen pots on March 20,2017. Crop was fertilized with NPK at 200, 150 and $150 \mathrm{~kg} \mathrm{ha}^{-1}$, respectively using urea $\left(\mathrm{NH}_{2}\right)_{2} \mathrm{CO}$, diammonium phosphate $\left(\mathrm{NH}_{4}\right)_{2} \mathrm{HPO}_{4}$ and $\mathrm{SOP}\left(\mathrm{K}_{2} \mathrm{SO}_{4}\right)$ as source of $\mathrm{N}, \mathrm{P}_{2} \mathrm{O}_{5}$ and $\mathrm{K}_{2} \mathrm{O}$, respectively. Completely randomized design (CRD) was used in laying out the experiment. Five replications $(n=5)$ were used for each treatment. Thinning was done at 20 days after 
sowing and three seedlings was maintained in each pot. A standard criterion for irrigation was followed (Ayer's and Westcot, 1985). Maize crop was harvested manually on May 20, 2017.

\subsection{Data collection}

\subsubsection{Germination count (\%) at 8 days after sowing}

After the eight days of sowing, germinating seedlings were counted, and germination percentage was noted by using the following formula:

$$
\text { Germination count }(\%)=\frac{\text { Total number of germinated seedlings }}{\text { Total number of seeds sown }} \times 100
$$

\subsubsection{Physiological parameters and enzymatic analysis}

Fresh leaf samples of maize were obtained at 40 days after sowing to measure the chlorophyll a \& b contents, carotenoids contents, antioxidant enzyme activity, photosynthetic rate, stomatal conductance, electrolyte leakage and relative water contents in leaves.

\subsubsection{Chlorophyll content determination}

Chlorophyll contents were measured by grinding the $250 \mathrm{mg}$ of fresh leaf samples in liquid nitrogen. A 10 $\mathrm{mL}$ volume of acetone/water (80/20: v/v) were added in the sample and kept at $4^{\circ} \mathrm{C}$ for $24 \mathrm{~h}$. After the 24 $\mathrm{h}$, the samples were centrifuged at $10000 \mathrm{~g}$ for $10 \mathrm{~min}$ and the supernatant was collected in falcon tubes. Absorbance of the samples was recorded at 470,646 and $663.2 \mathrm{~nm}$. Chlorophyll contents were determined by using the procedure adopted by Lictenthaler (1987).

\subsubsection{Antioxidant enzyme analysis}

For the analysis of antioxidants enzymes, fresh leaves of maize were minced in liquid nitrogen. The grinded sample was homogenized in phosphate buffer $(0.05 \mathrm{M}$ and $\mathrm{pH}=7.1)$. The homogenized sample was filtered and centrifuged at $16000 \mathrm{~g}$ for $10 \mathrm{~min}$ at $4{ }^{\circ} \mathrm{C}$. By adopting the procedure designated by Aebi (1984), activity of catalase enzyme was measured. In this procedure, the enzyme extract was mixed with $300 \mathrm{mM} \mathrm{H}_{2} \mathrm{O}_{2}$, phosphate buffer $(50 \mathrm{mM})$ and $\mathrm{CA}(2.0 \mathrm{mM}, \mathrm{pH} 7.0)$. Due to $\mathrm{H}_{2} \mathrm{O}_{2}$ disappearance $\left(\varepsilon^{1 / 1} 439.4\right.$ $\left.\mathrm{mM}^{-1} \mathrm{~cm}^{-1}\right)$, diminution in absorbance at $240 \mathrm{~nm}$ was measured.

Activity of ascorbate peroxidase (APX) enzyme was measured using the method described by Nakano and Asada (1981). For this method, $100 \mu \mathrm{L}$ enzyme extract was mixed with equal volume of $7.5 \mathrm{mM}$ ascorbate and $300 \mathrm{mM} \mathrm{H}_{2} \mathrm{O}_{2}, 2.7 \mathrm{~mL}$ of $25 \mathrm{mM}$ potassium phosphate buffer and $2.0 \mathrm{mM}$ ethylenediaminetetraacetic acid $\left(\mathrm{C}_{10} \mathrm{H}_{16} \mathrm{~N}_{2} \mathrm{O}_{8}\right)$ (neutral $\mathrm{pH}$ ). To measure the ascorbate oxidation activity, wavelength at $290 \mathrm{~nm}$ was noted. 
Peroxidation of lipids in leaf tissue is represented by malondialdehyde (MDA) contents and this was measured by using thiobarbituric acid-reactive-substances assay (TBARS; Heath and Packer, 1968). For this, $0.25 \mathrm{~g}$ of fresh leaves were mixed with trichloro acetic acid (TCA) and centrifugation was done at $12000 \mathrm{~g}$ for $15 \mathrm{~min}$. The supernatant was separated, and $1.0 \mathrm{~mL}$ of the supernatant was mixed with 4.0 $\mathrm{mL}$ of $20 \%$ TCA comprising $0.5 \%$ thiobarbituric acid (TBA). The mixture was placed at $95{ }^{\circ} \mathrm{C}$ for $30 \mathrm{~min}$. After the heating, it was rapidly cooled in an ice bath and centrifuged at $10,000 \mathrm{~g}$ for $10 \mathrm{~min}$. The supernatant was analyzed on spectrophotometer at $532 \mathrm{~nm}$ and value for nonspecific absorbance at 600 $\mathrm{nm}$ was deducted. Using extinction coefficient of $155 \mathrm{mM}^{-1} \mathrm{~cm}^{-1}$, the calculation of MDA contents was made.

\subsubsection{Photosynthetic rate and stomatal conductance}

Stomatal conductance and rate of photosynthesis were measured on portable Infra-red Gas Analyzer (IRGA; LCA-4; Analytical Development Company, Hoddeson, UK) by using the condition reported previously (Ben-Asher et al., 2006). Fully expanded flag leaves of maize were used to note the IRGA readings at a specific time i.e. at 10:00 to 11:00 a.m.

\subsubsection{Relative water content and electrolyte leakage}

Method of Mayak et al. (2004) was used to measure the relative water contents (RWC) in maize. Fresh leaves of maize were taken and weighed to get leaf fresh biomass. The leaves were then placed in water for overnight. After that, weight of the leaves was noted (i.e. fully turgid weight). To measure the oven dried biomass, the fully turgid leaves were dried in an oven at $70 \pm 2{ }^{\circ} \mathrm{C}$ for $48 \mathrm{~h}$.

$$
\mathrm{RWC}=\frac{\text { fresh biomass-dry biomass }}{\text { plant turgid biomass }- \text { dry biomass }} \times 100
$$

The method described by Ahmad et al. (2014) was used to measure the electrolyte leakage (ELL). In this method, completely extended flag leaf was cut into pieces of about $5 \mathrm{~mm}$ length. These pieces were placed in test tubes filled with $10 \mathrm{~mL}$ doble distilled water. The tubes were kept on shaking at $150 \mathrm{~g}$ and $30^{\circ} \mathrm{C}$ for $4 \mathrm{~h}$. After that, the electrical conductivity (EC1) of the medium was noted. Then all the test tubes were autoclaved by placing them in an autoclave and cooled down to $25^{\circ} \mathrm{C}$. Afterwards, electrical conductivity (EC2) of the cooled samples was measured. ELL was calculated by:

$$
\text { Electrolyte leakage }(\mathrm{ELL})=\frac{\mathrm{EC} 1}{\mathrm{EC} 2} \times 100
$$

\subsubsection{Measurement of growth data}


Maize plants were harvested on May 20, 2017 i.e. at 60 days after sowing. At the time of harvesting, maize plants were uprooted, and roots were separated from each plant. The separated roots were washed in tap water and placed separately on a transparent polyethylene sheet. The sheet along with the roots were placed on desktop scanner. The roots were scanned, root image was created on computer and the root length was measured using root image analysis program. Shoot length of each plant was measured with measuring tape. At the time of harvesting, fresh weight of both root and shoot were measured separately with the help of laboratory weighing balance. After measuring the fresh weight, root and shoot were kept in an oven at $70^{\circ} \mathrm{C}$ for $48 \mathrm{~h}$ and weighed separately on digital balance to measure dry weight.

\subsubsection{Organic acids detection in root exudates of maize}

Root samples were collected from each treatment at flag leaf stage. The roots were placed in $30 \mathrm{~mL}$ sterilized distilled water and kept on shaking at $150 \mathrm{~g}$ for 5 days. Thereafter, supernatant of samples was collected through centrifuge at $6000 \mathrm{~g}$ for $8 \mathrm{~min}$ and concentrated to $1.5 \mathrm{~mL}$ in a concentrator (Concentrator 5301, Eppendorf, Germany) and filtered over a $0.2 \mu \mathrm{m}$ filter (Orange Scientific GyroDisc CAPC, Belgium). To determine the organic acids (acetic acid and citric acid), the filtrates were analyzed by HPLC, using a Perkin Elmer series 200 with $20 \mu$ L auto-sampler PE NELSON 900 series interface, PE NELSON 600 series link and Perkin Elmer NCl 900 Network Chromatography interface using Diode-array detector at $210 \mathrm{~nm}$ and their UV spectra (190-400 nm), Microgaurd Cation-H Precolumn and an Aminex $\mathrm{HPx}-87 \mathrm{H}$ analytical column for separation. Sulfuric acid $(0.001 \mathrm{~N})$ was used as mobile phase with flow rate of $0.6 \mathrm{~mL} \mathrm{~min}{ }^{-1}$. The run was isocratic, and the run time of each sample was $20 \mathrm{~min}$. Solutions (100 $\mu \mathrm{g} \mathrm{L}^{-1}$ ) of acetic and citric acid (Daejung, Korea) were used as standards.

\subsubsection{Cadmium concentration in plant tissue (root and shoot)}

The root and shoot samples were kept in oven at $70{ }^{\circ} \mathrm{C}$ for $24 \mathrm{~h}$ to get oven dried. The dried samples were weighed on digital balance. After weighing, the samples were mashed, and digested with nitric acid $\left(\mathrm{HNO}_{3}\right)$ and perchloric $\left(\mathrm{HClO}_{4}\right)$ acid (3:1 ratio). The digested samples were placed on a hot plate for heating at $350^{\circ} \mathrm{C}$ until the dense white fumes produced. The samples were then cooled, passed through a Whatman 40, and stored. The $\mathrm{Cd}$ in the filtered samples was determined on atomic absorption spectrophotometer wit detection limit of $0.002 \mathrm{\mu g} \mathrm{L}^{-1}$ (PerkinElmer, 100 Analyst, Waltham, USA). Translocation factor (TF) was measured according to Ahmad et al. (2014).

\subsection{Statistical analysis}

Normal distribution ( $P>0.05)$ test on all the data collected was performed according to Shapiro-Wilk test. Levene test was performed to verify the homogeneity of variance $(P>0.05)$ of sample data. Statistix v8.1 was used to analyze the data statistically using one-way analysis of variance (ANOVA). The data presented here is the average of five replicates $(n=5) \pm$ standard error. Linear regression analysis was applied to determine relation of $\mathrm{Cd}$ concentration in maize plant to organic acids concentration in root exudates of maize. When the overall, main effect was significant, treatments mean was further compared using LSD test at $P<0.05$ probability level (Steel et al., 1997). 


\section{Results}

\subsection{Minimum inhibitory concentration of cadmium}

The PBR strain Pantoea sp. WP-5 showed tolerance up to $1000 \mathrm{mg} \mathrm{L}^{-1}$ of $\mathrm{Cd}$, further increase in Cd concentration inhibited the growth of this strain.

\subsection{Pot experiment}

\subsubsection{Germination count (\%) at 8 days after sowing}

Analysis of data revealed that BGR treatment gave significantly higher germination percentage (60\%) under $\mathrm{Cd}$ stress conditions at 8 days after sowing (DAS; Fig. 1a). The treatments MtPBR + BGR, MtPBR + $\mathrm{PM}$ and MtPBR + BGR + PM resulted in $57 \%$ germination count in Cd contaminated soil. Minimum values of germination percentage i.e. $43 \%$ was recorded in control treatment in $\mathrm{Cd}$ contaminated soil. Under no Cd stress, the MtPBR + BGR resulted in higher germination count (60\%) at 8 DAS (Fig. 1a).

\subsubsection{Plant height $(\mathrm{cm})$ and dry weight (g per plant)}

Under normal soil conditions, MtPBR + BGR gave higher plant height $(104 \mathrm{~cm})$ and plant dry weight $(25.9$ g per pot) as compared to all other treatments (Table 1). Application of PM, PM + MtPBR and PM + BGR resulted in plants of height $96 \mathrm{~cm}, 92.8$ and $85.5 \mathrm{~cm}$ respectively, under normal soil conditions. The treatments $\mathrm{PM}+\mathrm{BGR}$ and MtPBR $+\mathrm{BGR}+\mathrm{PM}$ produced $19.6 \mathrm{~g} \mathrm{pot}^{-1}$ and $18 \mathrm{~g} \mathrm{pot}^{-1}$ plant biomass respectively, under normal soil conditions. In Cd contaminated soil, the treatment (MtPBR + BGR) produced significantly $(P<0.05)$ higher plant height $(97.2 \mathrm{~cm})$ and plant dry weight $(18.0 \mathrm{~g}$ per pot). The treatments MtPBR + PM, BGR + PM and MtPBR + BGR + PM gave plant height $92.3 \mathrm{~cm}, 86.0 \mathrm{~cm}$, and 87.7 $\mathrm{cm}$ respectively, in Cd contaminated soil (Table 1). The treatment MtPBR + PM and MtPBR + BGR + PM produced $15.2 \mathrm{~g} \mathrm{pot}^{-1}$ and $15.0 \mathrm{~g} \mathrm{pot}^{-1}$ plant biomass respectively, in Cd contaminated soil. Minimum values of these parameters were recorded in control treatment under both the soil conditions. 
Table 1

Effect of Pantoea sp. strain WP-5 and organic amendments on maize plant height, biomass, and physiology in normal and Cd contaminated soils

\begin{tabular}{|c|c|c|c|c|c|c|}
\hline Treatments & & $\begin{array}{l}\text { Plant } \\
\text { biomass } \\
\text { (g pot } \\
\text { 1) }\end{array}$ & $\begin{array}{l}\text { Plant } \\
\text { height } \\
\text { (cm) }\end{array}$ & $\begin{array}{l}\text { Photosynthetic } \\
\text { rate } \\
\left(\mu \mathrm{mol} \mathrm{CO}_{2} \mathrm{~m}^{-}\right. \\
\left.2 \mathrm{~s}^{-1}\right)\end{array}$ & $\begin{array}{l}\text { Stomatal } \\
\text { conductance ( } \mu \mathrm{mol} \\
\left.\mathrm{CO}_{2} \mathrm{~mol} \mathrm{air}^{-1}\right)\end{array}$ & $\begin{array}{l}\text { RWC } \\
\text { (\%) }\end{array}$ \\
\hline \multirow[t]{8}{*}{ Normal soil } & MtPBR & $\begin{array}{l}14.1 \pm \\
0.5 \mathrm{~d}\end{array}$ & $\begin{array}{l}76.5 \pm \\
1.0 \mathrm{~g}\end{array}$ & $22 \pm 0.7 b c$ & $3.55 \pm 0.10 b c$ & $\begin{array}{l}72 \pm \\
1.1 \mathrm{c}\end{array}$ \\
\hline & BGR & $\begin{array}{l}11.5 \pm \\
1 \mathrm{e}\end{array}$ & $\begin{array}{l}70.5 \pm \\
1.0 \mathrm{~g}\end{array}$ & $21 \pm 0.5 c$ & $3.50 \pm 0.12 c$ & $\begin{array}{l}70 \pm \\
1.1 \mathrm{~d}\end{array}$ \\
\hline & PM & $\begin{array}{l}2.9 \pm \\
0.7 \mathrm{i}\end{array}$ & $\begin{array}{l}96.0 \pm \\
1.0 \mathrm{~b}\end{array}$ & $21 \pm 0.6 c$ & $3.43 \pm 0.13 \mathrm{~cd}$ & $\begin{array}{l}71 \pm \\
1.0 \mathrm{~cd}\end{array}$ \\
\hline & $\begin{array}{l}\text { MtPBR + } \\
\text { BGR }\end{array}$ & $\begin{array}{l}25.9 \pm \\
2 a\end{array}$ & $\begin{array}{l}104.0 \pm \\
1.0 \mathrm{a}\end{array}$ & $24 \pm 0.4 a$ & $3.83 \pm 0.11 a$ & $\begin{array}{l}85 \pm \\
1.0 \mathrm{a}\end{array}$ \\
\hline & $\begin{array}{l}\text { MtPBR + } \\
\text { PM }\end{array}$ & $\begin{array}{l}16.7 \pm \\
0.8 \mathrm{c}\end{array}$ & $\begin{array}{l}92.8 \pm \\
1.0 \mathrm{bc}\end{array}$ & $22 \pm 0.5 b c$ & $3.55 \pm 0.11 b c$ & $\begin{array}{l}78 \pm \\
1.2 \mathrm{~b}\end{array}$ \\
\hline & $\begin{array}{l}\text { BGR + } \\
\text { PM }\end{array}$ & $\begin{array}{l}19.6 \pm \\
0.5 b\end{array}$ & $\begin{array}{l}85.5 \pm \\
0.2 \mathrm{de}\end{array}$ & $21 \pm 0.5 c$ & $3.52 \pm 0.13 c$ & $\begin{array}{l}73 \pm \\
1.3 c\end{array}$ \\
\hline & $\begin{array}{l}\text { MtPBR + } \\
\text { BGR + } \\
\text { PM }\end{array}$ & $\begin{array}{l}18.0 \pm \\
0.5 b c\end{array}$ & $\begin{array}{l}83.0 \pm \\
3.0 \mathrm{de}\end{array}$ & $23 \pm 0.5 b$ & $3.65 \pm 0.12 a b$ & $\begin{array}{l}80 \pm \\
1.0 \mathrm{~b}\end{array}$ \\
\hline & Control & $\begin{array}{l}1.4 \pm \\
0.5 \mathrm{ij}\end{array}$ & $\begin{array}{l}43.2 \pm \\
4.0 \mathrm{hi}\end{array}$ & $20 \pm 0.5 d$ & $3.40 \pm 0.10 d$ & $\begin{array}{l}65 \pm \\
1.1 \mathrm{e}\end{array}$ \\
\hline \multirow[t]{6}{*}{$\begin{array}{l}\text { Cd } \\
\text { contaminated }\end{array}$} & PGPR & $\begin{array}{l}8.0 \pm \\
0.7 f\end{array}$ & $\begin{array}{l}80.8 \pm \\
1.0 \mathrm{ef}\end{array}$ & $17 \pm 0.4 f$ & $2.52 \pm 0.12 \mathrm{~g}$ & $\begin{array}{l}59 \pm \\
1.0\end{array}$ \\
\hline & BGR & $\begin{array}{l}4.7 \pm \\
0.5 \mathrm{~h}\end{array}$ & $\begin{array}{l}39.0 \pm \\
4.0 \mathrm{i}\end{array}$ & $16 \pm 0.5 \mathrm{~g}$ & $2.46 \pm 0.15 g$ & $\begin{array}{l}58 \pm \\
1.2 \mathrm{~h}\end{array}$ \\
\hline & PM & $\begin{array}{l}0.9 \pm \\
0.2 \mathrm{j}\end{array}$ & $\begin{array}{l}45.6 \pm \\
1.0 \mathrm{~h}\end{array}$ & $16 \pm 0.7 g$ & $2.22 \pm 0.14 h$ & $\begin{array}{l}57 \pm \\
1.3\end{array}$ \\
\hline & $\begin{array}{l}\text { MtPBR + } \\
\text { BGR }\end{array}$ & $\begin{array}{l}18.0 \pm \\
0.5 \mathrm{bc}\end{array}$ & $\begin{array}{l}97.2 \pm \\
1.0 \mathrm{~b}\end{array}$ & $19 \pm 0.6 \mathrm{de}$ & $3.00 \pm 0.10 \mathrm{e}$ & $\begin{array}{l}65 \pm \\
1.0 \mathrm{e}\end{array}$ \\
\hline & $\begin{array}{l}\text { MtPBR + } \\
\text { PM }\end{array}$ & $\begin{array}{l}15.2 \pm \\
0.5 \mathrm{~d}\end{array}$ & $\begin{array}{l}92.3 \pm \\
1.5 \mathrm{bc}\end{array}$ & $17 \pm 0.5 f$ & $2.42 \pm 0.13 \mathrm{gh}$ & $\begin{array}{l}61 \pm \\
1.1 \mathrm{fg}\end{array}$ \\
\hline & $\begin{array}{l}\text { BGR + } \\
\text { PM }\end{array}$ & $\begin{array}{l}6.4 \pm \\
0.5 \mathrm{~g}\end{array}$ & $\begin{array}{l}86.0 \pm \\
0.2 \mathrm{de}\end{array}$ & $16 \pm 0.5 \mathrm{~g}$ & $2.35 \pm 0.12 \mathrm{gh}$ & $\begin{array}{l}60 \pm \\
1.2 \mathrm{~g}\end{array}$ \\
\hline
\end{tabular}

Values are the means $( \pm S E)$ of five replicates $(n=5)$. Different letters within columns show statistically significant difference $(P \leq 0.05)$ while the values sharing the same letter are statistically non-significant following least significant difference (LSD) test. (RWC = relative water contents) 


\begin{tabular}{|c|c|c|c|c|c|c|}
\hline \multicolumn{2}{|l|}{ Treatments } & $\begin{array}{l}\text { Plant } \\
\text { biomass } \\
\text { (g pot } \\
\text { 1) }\end{array}$ & $\begin{array}{l}\text { Plant } \\
\text { height } \\
\text { (cm) }\end{array}$ & $\begin{array}{l}\text { Photosynthetic } \\
\text { rate } \\
\left(\mu \mathrm{mol} \mathrm{CO} \mathrm{m}^{-}\right. \\
\left.2 \mathrm{~s}^{-1}\right)\end{array}$ & $\begin{array}{l}\text { Stomatal } \\
\text { conductance }(\mu \mathrm{mol} \\
\left.\mathrm{CO}_{2} \text { mol air }^{-1}\right)\end{array}$ & $\begin{array}{l}\text { RWC } \\
(\%)\end{array}$ \\
\hline & $\begin{array}{l}\text { MtPBR + } \\
\text { BGR + } \\
\text { PM }\end{array}$ & $\begin{array}{l}15.0 \pm \\
0.8 d\end{array}$ & $\begin{array}{l}87.7 \pm \\
0.5 \mathrm{~cd}\end{array}$ & $18 \pm 0.7 e$ & $2.75 \pm 0.11 f$ & $\begin{array}{l}63 \pm \\
1.1 f\end{array}$ \\
\hline & Control & $\begin{array}{l}0.8 \pm \\
0.4 \mathrm{j}\end{array}$ & $\begin{array}{l}41.0 \pm \\
2.5 \mathrm{hi}\end{array}$ & $15 \pm 0.4 h$ & $2.00 \pm 0.10 \mathrm{i}$ & $\begin{array}{l}55 \pm \\
1.0 \mathrm{i}\end{array}$ \\
\hline & LSD & 6.0 & 7.0 & 3 & 0.5 & 4.0 \\
\hline & $\begin{array}{l}(P \leq \\
0.05)\end{array}$ & 0.001 & 0.001 & 0.005 & 0.001 & 0.02 \\
\hline $\begin{array}{l}\text { Values are } \\
\text { statistically } \\
\text { non-signific }\end{array}$ & $\begin{array}{l}\text { ans }( \pm \text { SE } \\
\text { cant diff } \\
\text { lowing le }\end{array}$ & $\begin{array}{l}\text { five rep } \\
\text { ce }(P \leq \\
\text { significa }\end{array}$ & $\begin{array}{l}\text { es (n } \\
\text { whi } \\
\text { iffere }\end{array}$ & $\begin{array}{l}\text { ifferent letters } \\
\text { values sharing } \\
\text { SD) test. (RWC }\end{array}$ & $\begin{array}{l}\text { hin columns show } \\
\text { same letter are stat } \\
\text { elative water conten }\end{array}$ & cally \\
\hline
\end{tabular}

\subsubsection{Physiological parameters of maize}

Under normal soil conditions, the treatment MtPBR + BGR increased the photosynthetic rate, stomatal conductance and RWC by $20 \%, 13 \%$ and $31 \%$ respectively, over control treatment. Under Cd stress conditions, the treatment MtPBR + BGR showed significantly $(P<0.05)$ higher photosynthetic rate (19 $\left.\mu \mathrm{mol} \mathrm{CO} \mathrm{Cm}^{-2} \mathrm{~s}^{-1}\right)$, stomatal conductance $\left(3 \mu \mathrm{mol} \mathrm{CO} \mathrm{Col}_{2} \mathrm{mor}^{-1}\right)$ and RWC (65\%) as compared to all other treatments (Table 1). However, the treatment MtPBR + BGR + PM increased the photosynthetic rate, stomatal conductance and RWC by $20 \%, 38 \%$ and $15 \%$ over control treatment in Cd contaminated soil. Application of MtPBR as sole treatment in normal soil also performed well and increased the photosynthetic rate by $10 \%$, stomatal conductance by $4 \%$ and RWC by $11 \%$ over the control treatment. While in Cd contaminated soil the MtPBR as sole application increased the photosynthetic rate by $13 \%$, stomatal conductance by $26 \%$ and RWC by $7 \%$ over the control treatment. Minimum values of these parameters were recorded in the control treatment under normal as well as $\mathrm{Cd}$ stress conditions (Table 1).

Under normal soil conditions, the application of PM alone and MtPBR + BGR + PM gave significantly $(P<$ 0.05) higher chlorophyll a content i.e. 2.07 and $2.02 \mathrm{mg} \mathrm{g}^{-1}$ leaf fresh weight respectively, as compared to all other treatments (Fig. 1b). In the Cd contaminated soil, the treatment MtPBR + BGR gave higher chlorophyll a content i.e. $1.87 \mathrm{mg} \mathrm{g}^{-1}$ leaf fresh weight as compared to other treatments in $\mathrm{Cd}$ contaminated soil (Fig. 1b). The control treatment resulted in minimum chlorophyll a content under normal as well as under $\mathrm{Cd}$ stress conditions.

Application of MtPBR as sole treatment gave significantly $(P<0.05)$ higher chlorophyll $b$ content $(1.5 \mathrm{mg}$ $\mathrm{g}^{-1}$ leaf fresh weight) as compared to other treatments under normal soil conditions (Fig. 1c). After the MtPBR treatment, the treatments BGR, BGR + PM and MtPBR + BGR + PM produced chlorophyll $b$ content 
$0.8,0.76$ and $0.78 \mathrm{mg} \mathrm{g}^{-1}$ leaf fresh weight respectively, under the normal soil conditions. In Cd contaminated soil, the MtPBR as sole treatment gave significantly $(P<0.05)$ higher chlorophyll $b$ content ( $0.95 \mathrm{mg} \mathrm{g}^{-1}$ leaf fresh weight) as compared to the other treatments. After the MtPBR treatments, the treatments BGR, MtPBR + BGR, BGR + PM and MtPBR + BGR + PM also increased the chlorophyll $b$ contents by $93 \%, 73 \%, 118 \%$ and $103 \%$ respectively, over the control treatment in Cd contaminated soil (Fig. 1c).

In normal soil, the application of MtPBR as sole treatment resulted in significantly $(P<0.05)$ higher carotenoid contents i.e. $2.01 \mathrm{mg} \mathrm{g}^{-1}$ leaf fresh weight. After the MtPBR treatment, the treatment MtPBR + BGR produced higher carotenoids content $\left(1.13 \mathrm{mg} \mathrm{g}^{-1}\right.$ leaf fresh weight) in normal soil (Fig. 1d). In Cd contaminated soil, the treatment MtPBR + BGR gave significantly $(P<0.05)$ higher carotenoid contents (1.06 $\mathrm{mg} \mathrm{g}^{-1}$ leaf fresh weight) as compared to the other treatments. Minimum carotenoids were measured in the control treatments under normal as well as under $\mathrm{Cd}$ stress conditions.

Membrane damage was determined by measuring the ELL. It was noted that ELL was significantly $(P<$ 0.05) higher in plants grown in Cd contaminated soil as compared to that of the plants in normal soil (Fig. 2a). Among the treatments, the values of ELL were significantly $(P<0.05)$ higher in control treatment i.e. $61.6 \%$ in Cd contaminated soil and $40.5 \%$ in normal soil. Application of organic amendments either alone or in combined form tended to decrease the ELL value. In normal soil, the treatment MtPBR + BGR reduced the ELL value up to $28.2 \%$ while in Cd contaminated soil the same treatment reduced the ELL value up to $45 \%$ (Fig. 2a).

\subsubsection{Antioxidant enzyme analysis}

Effect of Cd doses and organic amendments was observed significant $(P<0.05)$ on APX, catalase and MDA contents in leaves of maize. Analysis of data indicated APX production was higher in plants grown in Cd contaminated soil as compared to that in normal soil. Among the treatments, the control treatment resulted in significantly higher APX concentration $\left(162.0 \mathrm{~g}^{-1} \mathrm{fwt}\right.$ and $57.8 \mathrm{~g}^{-1}$ fwt respectively in Cd contaminated and normal soil) in leaves of maize as compared to all other treatments (Fig. 2b). Organic amendments reduced the values of APX in normal and Cd contaminated soil. In normal soil, APX concentration $\left(29.8 \mathrm{~g}^{-1} \mathrm{fwt}\right)$ was recorded significantly $(P<0.05)$ lower in leaves of MtPBR + BGR + PM treated plants. The values of APX in the MtPBR + BGR treated plants was $30.1 \mathrm{~g}^{-1}$ fwt in normal soil. In Cd contaminated soil, the values of APX were $128.2 \mathrm{~g}^{-1} \mathrm{fwt}$ and $129.5 \mathrm{~g}^{-1} \mathrm{fwt}$, respectively due to application of MtPBR + BGR and MtPBR + BGR + PM (Fig. 2b). The application of MtPBR as sole treatment gave APX value $132.5 \mathrm{~g}^{-1} \mathrm{fwt}$ in Cd contaminated soil and $33.5 \mathrm{~g}^{-1} \mathrm{fwt}$ in normal soil.

Catalase activity was recorded higher $\left(80.9 \mathrm{~g}^{-1} \mathrm{fwt}\right.$ and $70.8 \mathrm{~g}^{-1} \mathrm{fwt}$, respectively under $\mathrm{Cd}$ stress and normal soil conditions) in control treatment as compared to all other treatments (Fig. 2c). Minimum catalase concentration $\left(61.0 \mathrm{~g}^{-1} \mathrm{fwt}\right)$ was recorded in leaves of MtPBR + BGR + PM treated plants grown in Cd contaminated soil. The treatment MtPBR + BGR showed $62.1 \mathrm{~g}^{-1} \mathrm{fwt}$ catalase activity in Cd 
contaminated soil. While in normal soil, the values of catalase activity were 42.1 and $44.2 \mathrm{~g}^{-1} \mathrm{fwt}$, respectively in MtPBR + BGR + PM and MtPBR + BGR treatments. Application of treatments like PM, BGR and MtPBR as sole treatment also performed better. Sole application of MtPBR showed catalase activity $65.3 \mathrm{~g}^{-1} \mathrm{fwt}$ in Cd contaminated soil and $48.4 \mathrm{~g}^{-1} \mathrm{fwt}$ in normal soil which were much lesser than control and sole application of PM and BGR.

The control treatment produced significantly higher contents of MDA i.e., $11.6 \mu \mathrm{M} \mathrm{g}^{-1}$ fwt and $6.0 \mu \mathrm{M} \mathrm{g}^{-1}$ fwt, respectively in leaves of plants grown under Cd stress and normal soil conditions (Fig. 2d). Minimum MDA contents i.e. $5.8 \mu \mathrm{M} \mathrm{g}^{-1}$ fwt were recorded in leaves of MtPBR + BGR and $6.2 \mu \mathrm{M} \mathrm{g}^{-1} \mathrm{fwt}$ in MtPBR $+B G R+P M$ treated plants grown in Cd contaminated soil. In normal soil, the values of MDA contents were $2 \mu \mathrm{M} \mathrm{g}^{-1}$ fwt in MtPBR + BGR and $3.2 \mu \mathrm{M} \mathrm{g}^{-1} \mathrm{fwt}$ in MtPBR + BGR + PM treated plants. The sole application of MtPBR showed MDA contents i.e. $7.1 \mu \mathrm{M} \mathrm{g}^{-1}$ fwt in Cd contaminated soil and $4.2 \mu \mathrm{M} \mathrm{g}^{-1}$ fwt in normal soil which were much lesser than the control.

\subsubsection{Number of roots (per plant), root length (cm) and root dry weight (g per plant)}

The treatment MtPBR + BGR gave significantly $(P<0.05)$ higher number of roots $(20.3 \pm 1$ roots per plants), root length $(40.7 \pm 1 \mathrm{~cm})$ and root dry weight $(2.80 \pm 0.2 \mathrm{~g}$ per plant) as compared to control and all other treatments in Cd contaminated soil (Table 2). The BGR application as sole treatment gave number of roots ( $18 \pm 0.5$ roots per plant) and root length $40 \pm 2 \mathrm{~cm}$ which were much higher than control treatment in Cd contaminated soil. Under normal soil conditions, the treatment MtPBR + BGR gave significantly higher number of roots i.e. 29.5 roots per plant, root length i.e. $58.8 \mathrm{~cm}$ and dry weight i.e. $4.15 \mathrm{~g}$ per plant as compared to all other treatments (Table 2). The treatment MtPBR + BGR + PM produced $26.0 \pm 1$ number of roots per plant and root dry weight $2.88 \mathrm{~g}$ per plant in normal soil. The PM sole treatment gave $53.3 \pm 1$ root length in normal soil. Minimum values of all these parameters were recorded in the control treatment under both the soils conditions. 
Table 2

Effect of Pantoea sp. strain WP-5 and organic amendments on root growth and Cd concentration in maize (root + shoot) in normal as well as Cd contaminated soils

\begin{tabular}{|c|c|c|c|c|c|c|}
\hline Treatments & & $\begin{array}{l}\text { Number of roots } \\
\text { plant }^{-1}\end{array}$ & $\begin{array}{l}\text { Root } \\
\text { length } \\
\text { (cm) }\end{array}$ & $\begin{array}{l}\text { Root dry } \\
\text { biomass } \\
\left.\text { (g plant }^{-1}\right)\end{array}$ & $\begin{array}{l}\text { Shoot Cd } \\
\text { (mg kg-1 } \\
\text { dwt) }\end{array}$ & $\begin{array}{l}\text { Root Cd } \\
\text { (mg kg-1 } \\
\text { dwt) }\end{array}$ \\
\hline \multirow[t]{8}{*}{ Normal soil } & PGPR & $19.5 \pm 1.0 d$ & $\begin{array}{l}34.2 \pm \\
0.5 \mathrm{~g}\end{array}$ & $\begin{array}{l}3.01 \pm \\
0.2 \mathrm{ab}\end{array}$ & $\begin{array}{l}2.33 \pm \\
0.5 \mathrm{hi}\end{array}$ & $\begin{array}{l}6.37 \pm \\
0.5 \mathrm{kl}\end{array}$ \\
\hline & BGR & $12.5 \pm 1.0 \mathrm{i}$ & $\begin{array}{l}33.8 \pm \\
1.0 \mathrm{gh}\end{array}$ & $\begin{array}{l}2.06 \pm \\
0.1 \mathrm{bc}\end{array}$ & $\begin{array}{l}3.4 \pm \\
0.6 \mathrm{ghi}\end{array}$ & $\begin{array}{l}9.52 \pm \\
0.8 \mathrm{jk}\end{array}$ \\
\hline & PM & $20.7 \pm 2.0 c$ & $\begin{array}{l}53.3 \pm \\
1.0 \mathrm{~b}\end{array}$ & $0.84 \pm 0.1 \mathrm{c}$ & $\begin{array}{l}5.23 \pm \\
0.3 \mathrm{gh}\end{array}$ & $3.33 \pm 0.5$ \\
\hline & $\begin{array}{l}\text { PGPR + } \\
\text { BGR }\end{array}$ & $29.5 \pm 1.0 a$ & $\begin{array}{l}58.8 \pm \\
2.0 a\end{array}$ & $4.15 \pm 0.2 a$ & $\begin{array}{l}0.50 \pm \\
0.1 \mathrm{i}\end{array}$ & $\begin{array}{l}16.07 \pm \\
1.0 \mathrm{i}\end{array}$ \\
\hline & $P G P R+P M$ & $17.0 \pm 1.0 \mathrm{ef}$ & $\begin{array}{l}38.0 \pm \\
2.0 \mathrm{ef}\end{array}$ & $\begin{array}{l}2.20 \pm \\
0.1 \mathrm{bc}\end{array}$ & $\begin{array}{l}1.33 \pm \\
0.1 \mathrm{hi}\end{array}$ & $4.23 \pm 0.5$ \\
\hline & $B G R+P M$ & $15.5 \pm 0.3 f g h$ & $\begin{array}{l}44.9 \pm \\
1.0 \mathrm{c}\end{array}$ & $\begin{array}{l}2.88 \pm \\
0.1 \mathrm{ab}\end{array}$ & $\begin{array}{l}2.9 \pm \\
0.2 \mathrm{ghi}\end{array}$ & $\begin{array}{l}6.13 \pm \\
0.5 \mathrm{kl}\end{array}$ \\
\hline & $\begin{array}{l}\mathrm{PGPR}+ \\
\mathrm{BGR}+\mathrm{PM}\end{array}$ & $26.0 \pm 1.0 b$ & $\begin{array}{l}41.5 \pm \\
1.0 \mathrm{~d}\end{array}$ & $\begin{array}{l}2.98 \pm \\
0.1 \mathrm{ab}\end{array}$ & $\begin{array}{l}1.33 \pm \\
0.2 \mathrm{hi}\end{array}$ & $\begin{array}{l}12.03 \pm \\
1.2 \mathrm{ij}\end{array}$ \\
\hline & Control & $13.0 \pm 0.5 \mathrm{hi}$ & $\begin{array}{l}31.3 \pm \\
0.5 \mathrm{i}\end{array}$ & $0.61 \pm 0.1 \mathrm{c}$ & $\begin{array}{l}6.63 \pm \\
0.5 \mathrm{~g}\end{array}$ & $2.30 \pm 0.5$ \\
\hline \multirow[t]{7}{*}{$\begin{array}{l}\text { Cd } \\
\text { contaminated }\end{array}$} & PGPR & $14.3 \pm 0.2 \mathrm{ghi}$ & $\begin{array}{l}28.3 \pm \\
0.5 \mathrm{jk}\end{array}$ & $2.34 \pm 0.1 \mathrm{a}$ & $\begin{array}{l}108.3 \pm \\
0.5 d\end{array}$ & $\begin{array}{l}159.00 \pm \\
2.5 \mathrm{~g}\end{array}$ \\
\hline & BGR & $18.0 \pm 0.5 \mathrm{def}$ & $\begin{array}{l}40.0 \pm \\
2 \mathrm{ef}\end{array}$ & $\begin{array}{l}1.38 \pm \\
0.2 \mathrm{bc}\end{array}$ & $\begin{array}{l}115.7 \pm \\
0.5 c\end{array}$ & $\begin{array}{l}288.33 \pm \\
3.0 \mathrm{c}\end{array}$ \\
\hline & PM & $13.0 \pm 0.5 \mathrm{hi}$ & $\begin{array}{l}30.0 \pm \\
0.5 i j\end{array}$ & $0.74 \pm 0.1 \mathrm{c}$ & $\begin{array}{l}135.3 \pm \\
1.2 \mathrm{~b}\end{array}$ & $\begin{array}{l}166.00 \pm \\
1.2 f\end{array}$ \\
\hline & $\begin{array}{l}\text { PGPR + } \\
\text { BGR }\end{array}$ & $20.3 \pm 1.0 \mathrm{~cd}$ & $\begin{array}{l}40.7 \pm \\
1.0 \mathrm{de}\end{array}$ & $\begin{array}{l}2.80 \pm \\
0.2 a b\end{array}$ & $\begin{array}{l}70.3 \pm \\
1.2 f\end{array}$ & $\begin{array}{l}385.00 \pm \\
2.6 a\end{array}$ \\
\hline & $P G P R+P M$ & $12.5 \pm 0.5 i$ & $\begin{array}{l}37.3 \pm \\
0.5 f\end{array}$ & $\begin{array}{l}1.90 \pm \\
0.2 \mathrm{bc}\end{array}$ & $\begin{array}{l}108.3 \pm \\
2.0 \mathrm{~d}\end{array}$ & $\begin{array}{l}213.33 \pm \\
2.3 e\end{array}$ \\
\hline & $B G R+P M$ & $17.5 \pm 0.5 \mathrm{ef}$ & $\begin{array}{l}26.7 \pm \\
1.2 \mathrm{k}\end{array}$ & $\begin{array}{l}1.78 \pm \\
0.2 b c\end{array}$ & $\begin{array}{l}138.3 \pm \\
1.2 \mathrm{~b}\end{array}$ & $\begin{array}{l}245.33 \pm \\
1.5 d\end{array}$ \\
\hline & $\begin{array}{l}\text { PGPR + } \\
\text { BGR + PM }\end{array}$ & $16.5 \pm 1.0 \mathrm{fg}$ & $\begin{array}{l}31.7 \pm \\
0.5 \mathrm{hi}\end{array}$ & $\begin{array}{l}1.72 \pm \\
0.2 \mathrm{bc}\end{array}$ & $\begin{array}{l}103.7 \pm \\
1.0 \mathrm{e}\end{array}$ & $\begin{array}{l}296.00 \pm \\
3.0 \mathrm{~b}\end{array}$ \\
\hline
\end{tabular}

Values are the means $( \pm S E)$ of five replicates $(n=5)$. Different letters within columns show statistically significant difference $(P \leq 0.05)$ while the values sharing the same letter are statistically non-significant following least significant difference (LSD) test. 


\begin{tabular}{|c|c|c|c|c|c|c|}
\hline Treatments & & $\begin{array}{l}\text { Number of roots } \\
\text { plant }^{-1}\end{array}$ & $\begin{array}{l}\text { Root } \\
\text { length } \\
\text { (cm) }\end{array}$ & $\begin{array}{l}\begin{array}{l}\text { Root dry } \\
\text { biomass }\end{array} \\
\left.\text { (g plant }^{-1}\right)\end{array}$ & $\begin{array}{l}\text { Shoot Cd } \\
\text { (mg kg-1 } \\
\text { dwt) }\end{array}$ & $\begin{array}{l}\text { Root Cd } \\
\text { (mg kg-1 } \\
\text { dwt) }\end{array}$ \\
\hline & Control & $13.0 \pm 0.5 \mathrm{hi}$ & $\begin{array}{l}27.5 \pm \\
0.5 \mathrm{k}\end{array}$ & $0.50 \pm 0.1 \mathrm{c}$ & $\begin{array}{l}179.7 \pm \\
1.5 a\end{array}$ & $\begin{array}{l}130.67 \pm \\
3.0 \mathrm{~h}\end{array}$ \\
\hline & LSD & 2.5 & 2.3 & 2.0 & 4.0 & 6.0 \\
\hline & $(P \leq 0.05)$ & 0.0001 & 0.02 & 0.02 & 0.001 & 0.01 \\
\hline
\end{tabular}

\subsubsection{Organic acid concentration in root exudates of maize ( $\mu \mathrm{g} \mathrm{g}^{-1}$ root fwt)}

Acetic and citric acid concentrations were recorded higher in root exudates of maize plants grown in Cdcontaminated soil as compared to that of normal soil (Fig. 2e \& 2f). Among the treatments, the application of MtPBR strain Pantoea sp. WP-5 either alone or in combination with BGR and PM resulted in higher secretion of acetic and citric acid concentrations in root exudates of maize (Fig. 2e \& 2f). Application of MtPBR + BGR produced significantly $(P<0.05)$ higher amount of acetic acid i.e. 52.7 and $40.5 \mu \mathrm{g} \mathrm{g}^{-1}$ root fresh weight, respectively in Cd contaminated and normal soil. The treatment MtPBR + $\mathrm{BGR}+\mathrm{PM}$ produced acetic acid $51.7 \mu \mathrm{g} \mathrm{g}^{-1}$ in Cd contaminated while $39.8 \mu \mathrm{g} \mathrm{g}^{-1}$ root fresh weight in normal soil. The sole application of MtPBR produced acetic acid by 39.7 and $30.5 \mu \mathrm{g} \mathrm{g}^{-1}$ root fresh weight in $\mathrm{Cd}$ and normal soils, respectively, which was higher than control treatment under both the soil conditions.

The treatment MtPBR + BGR gave significantly higher amount of citric acid i.e. $22.8 \mu \mathrm{g} \mathrm{g}^{-1}$ root fresh weight in Cd contaminated soil and $17.5 \mathrm{\mu g} \mathrm{g}^{-1}$ root fresh weight in normal soil as compared to all other treatments (Fig. 2e \& 2f). The values of citric acid produced in the treatment MtPBR + BGR + PM were at par with that of the treatment MtPBR + BGR under both the soil conditions. The sole application of MtPBR produced 16.5 and $12.7 \mu^{-1} \mathrm{~g}^{-1}$ root fresh weight citric acid in Cd contaminated and normal soil, respectively which were higher than that of the control treatment under both the soil conditions.

\subsubsection{Cadmium concentration in shoots and roots ( $\mathrm{mg} \mathrm{kg}$ $\left.{ }^{1} d w t\right)$}

Analysis of data revealed that control treatment showed higher concentration of Cd i.e. $179.7 \pm 1.5 \mathrm{mg}$ $\mathrm{kg}^{-1} \mathrm{dwt}$ in Cd contaminated while $6.63 \pm 0.5 \mathrm{mg} \mathrm{kg}^{-1} \mathrm{dwt}$ in normal soil in shoots of maize plants (Table 2). Poultry manure application either alone or with the BGR were the treatment after the control treatment that showed maximum concentration of Cd i.e. $135.3 \mathrm{mg} \mathrm{kg}^{-1} \mathrm{dwt}$ in Cd contaminated while 
$5.23 \mathrm{mg} \mathrm{kg}^{-1} \mathrm{dwt}$ in shoots of plants grown in normal soil. Minimum concentration of Cd i.e. $70.3 \pm 1.2$ and $0.50 \pm 0.1 \mathrm{mg} \mathrm{kg}^{-1} \mathrm{dwt}$ of shoots in Cd contaminated and normal soils respectively, was noted due to application of MtPBR + BGR treatment. The treatment MtPBR + BGR + PM gave Cd concentration $103.7 \pm$ $1 \mathrm{mg} \mathrm{kg}^{-1} \mathrm{dwt}$ of shoot in Cd contaminated soil while $1.33 \pm 0.2 \mathrm{mg} \mathrm{kg}^{-1} \mathrm{dwt}$ in normal soil (Table 2). The sole application of MtPBR gave Cd concentration $108.3 \pm 0.5 \mathrm{mg} \mathrm{kg}^{-1} \mathrm{dwt}$ in Cd contaminated while $2.33 \pm 0.5 \mathrm{mg} \mathrm{kg}^{-1} \mathrm{dwt}$ of shoot in normal soils.

The MtPBR + BGR treatment showed higher concentration of Cd in roots i.e. $385 \pm 2.6 \mathrm{mg} \mathrm{kg}^{-1} \mathrm{dwt}$ in Cd contaminated while $16.07 \pm 1 \mathrm{mg} \mathrm{kg}^{-1} \mathrm{dwt}$ in normal soil (Table 2). The treatment MtPBR + BGR + PM gave $\mathrm{Cd}$ concentrations $296 \pm 3 \mathrm{mg} \mathrm{kg}^{-1} \mathrm{dwt}$ of root in Cd contaminated while $12.03 \pm 1.2 \mathrm{mg} \mathrm{kg}^{-1} \mathrm{dwt}_{\text {in }}$ normal soil. The sole application of BGR gave Cd concentrations $288.3 \pm 3 \mathrm{mg} \mathrm{kg}^{-1} \mathrm{dwt}$ of root in Cd contaminated while $9.52 \pm 0.8 \mathrm{mg} \mathrm{kg}^{-1} \mathrm{dwt}$ in normal soil (Table 2).

\subsubsection{Translocation of $\mathrm{Cd}$}

Translocation factor (TF) measured based on root and shoot $\mathrm{Cd}$ concentrations. The values of TF were recorded maximum i.e. $2.88 \pm 0.2$ in control treatment (Fig. 3) in Cd contaminated soil. The various organic amendments tended to reduce the TF values. The treatment i.e. MtPBR + BGR showed significantly $(P<0.05)$ lower $(0.03 \pm 0.001$ and $0.18 \pm 0.08)$ TF value (Fig. 3$)$. The treatment MtPBR $+B G R$ $+\mathrm{PM}$ also showed reduced values of TF i.e. 0.11 in normal and 0.35 in $\mathrm{Cd}$ contaminated soil. The sole application of BGR gave lesser TF values i.e. 0.36 in normal and 0.40 in Cd contaminated soil but these values were higher than that of the treatment MtPBR + BGR and MtPBR + BGR + PM.

\subsubsection{Correlation analysis}

$\mathrm{Cd}$ concentration in shoots of maize was significantly negatively correlated with respective maize root exudates concentrations of citric and acetic acid in normal (Fig. $4 \mathrm{a}: \mathrm{R}^{2}=0.81 ; 4 \mathrm{e}: \mathrm{R}^{2}=0.87$ ) and $\mathrm{Cd}$ contaminated soil (Fig. 4c: $\mathrm{R}^{2}=0.86 ; 4 \mathrm{~g}: \mathrm{R}^{2}=0.90$ ). Similarly, root $\mathrm{Cd}$ concentration was significantly and positively correlated with respective maize root exudates concentrations of citric and acetic acid in normal (Fig. 4b: $\mathrm{R}^{2}=0.80 ; 4 f: \mathrm{R}^{2}=0.92$ ) and Cd contaminated soil (Fig. 4d: $\mathrm{R}^{2}=0.83 ; 4 \mathrm{~h}: \mathrm{R}^{2}=0.86$ ).

\section{Discussions}

The plant-beneficial rhizobacterial strain Pantoea sp. WP-5 is positive for IAA, phosphate solubilization and organic acid production (Tahir et al., 2020), here in this study, it was used as bioinoculant to maize grown in normal as well as in Cd contaminated soil because WP-5 strain showed Cd tolerance up to 1000 $\mathrm{mg} \mathrm{Cd} \mathrm{L^{-1 }}$ in a growth medium. These properties could enable this strain WP- 5 to sustain in Cd stress condition because bacterial produced organic acids (acetic acid, citric acid and gluconic acid) have number of functional groups like carboxylic group $(-\mathrm{COOH})$ that might have caused displacement of $\mathrm{Cd}$ through formation of either complexes or chelates with (Cd) ${ }^{2+}$ cations in solution (Bali et al., 2020; Mostofa et al., 2013; Potysz et al., 2017). In the present study, the increased concentration of acetic and 
citric acids in the root exudates of plants treated with MtPBR + BGR was due to the fact that the BGR helped the bacteria in multiplication and functioning which directly enhanced the organic acid secretion in root exudates of maize plants. The BGR role in improving bacterial multiplication and functioning in rhizosphere has been reported (Abubaker et al., 2012; Tahir et al., 2018). Concentration of Cd in roots of maize was higher in MtPBR inoculated treatment either alone or in combination with BGR under both the soil conditions in our study. Maize roots have potential to uptake $\mathrm{Cd}$ from soil and accumulate in roots (Puertas-Mejia et al. 2010; Ahmad et al., 2020) and the relationship between the Cd accumulation in roots and organic acids in root exudates has been reported (Najeeb et al., 2011). Our results indicated that MtPBR application increased the concentration of organic acids in root exudates of maize and the organic acids played a role in complexation, speciation, detoxification, and accumulation of $\mathrm{Cd}$ in roots of maize. Our results are in line with that of previous studies which reported the role of organic acids in $\mathrm{Cd}$ extraction from soil, Cd speciation and detoxification (Mostofa et al., 2013; Potysz et al., 2017; Bali et al., 2020). Uptake and accumulation of Cd in roots of maize (Puertas-Mejia et al., 2010; Ahmad et al., 2020) and the positive relationship of this trait with the organic acid concentration in root exudates of maize has been reported (Najeeb et al., 2011). Increased concentration of Cd in roots of maize due to PBR application has been reported (Moreira et al., 2014; Rizwan et al., 2016). Correlation analysis further confirmed our results which showed the significant positive relationship $\left(R^{2}=0.9\right.$ and 0.8 respectively, in Cd contaminated and normal soil; $P<0.05$ ) between $C d$ concentration in roots and the organic acid (acetic acid and citric acid) concentration in root exudates of maize. Translocation and concentration of Cd in shoots was recorded lower in MtPBR and MtPBR + BGR treatment as compared to control treatment in the present study. While the Cd translocation and concentration was higher in shoots of PM treated plants as compared to MtPBR + BGR treated plants in the present study. This indicated that the presence of MtPBR and BGR restricted whereas PM promoted the translocation of $\mathrm{Cd}$ to shoots. Results of some studies showed the increased translocation of $\mathrm{Cd}$ from roots to shoots particularly in stem due to application of organic manures, but this depends upon the nature and type of manure (Rizwan et al., 2016). Correlation analysis indicated that the significant negative correlation $\left(R^{2}=-0.9\right.$ and -0.8 respectively, in Cd contaminated and normal soil; $P<0.05$ ) exist between the organic acid concentration in root exudates and $\mathrm{Cd}$ concentration in shoots of maize. Progressive reduction in TF factor of $\mathrm{Cd}$ in maize when exposed to MtPBR + BGR treatment was observed in our study and has been reported previously (Ahmad et al., 2018).

Electrolyte leakage, MDA contents and antioxidant enzymes like APX and catalase activity was recorded higher in plants grown in Cd contaminated soil as compared to that of normal soil. Under the Cd contaminated soil conditions, plants faced osmotic stress that caused membrane damage resulting in increased ELL, MDA, APX and catalase contents. The values of these parameters were decreased by the application of organic amendments like MtPBR and BGR either alone or in combine form in the present study. The decrease in ELL, MDA, APX and catalase contents in PBR and BGR treatments indicated that these treatments tended to mitigate the $\mathrm{Cd}$ stress effects on plants. This was clearly due to the fact that the application of these treatments increased the organic acids production (acetic and citric acid in root exudates) in maize roots which resulted in increased Cd extraction from soil, Cd concentration in roots 
and restricted the translocation of Cd to shoots (low TF values). This ultimately resulted in the reduced $\mathrm{Cd}$ toxicity to maize plants and decreased the values of ELL, MDA, APX and catalase contents. Our results are similar with previous studies (Ahmad et al., 2018) who reported the increased ELL, MDA, APX and catalase level in plants under metal stress and the application of organic amendments tended to decrease the values of these parameters (Ahmad et al., 2018). These mechanisms enable the maize plants to cope with $\mathrm{Cd}$ stress and resulted in increased values of plant physiological parameters like stomatal conductance, photosynthetic rate and leaf relative water contents of maize in our study, and confirmed the previous findings (Ahmad et al., 2018). Plant growth parameters like plant height, number of roots, root length, root dry matter and plant dry matter were increased due to PBR and BGR application either alone or in combine form over control treatment in our study. This might be due to the fact that the application of PBR and BGR improved the concentration of $\mathrm{Cd}$ in roots of maize but restricted its translocation to shoot. The restricted translocation of $\mathrm{Cd}$ to shoot caused in lower/no toxicity of $\mathrm{Cd}$ in maize, which resulted in decreased membrane damage, increased photosynthetic activity, plant growth and dry matter yield in the present study. Increased plant growth and dry matter yield due application of organic manures in Cd contaminated soil have been reported in previous studies (Ahmad et al. 2015; Putwattana et al. 2015). Similarly, increased uptake of $\mathrm{Cd}$ from soil and accumulation in roots and improved maize growth as well as dry matter yield due to application of plant growth promoting rhizobacteria has been reported in previous studies (Ahmad et al., 2015; Sangthong et al., 2015; Moreira et al., 2014).

Application of PM resulted in decreased plant growth and dry matter yield in our study while Shumba et al. (2014) reported an increase in dry matter yield of maize due to PM application in sandy soil. This might be due to higher translocation of $\mathrm{Cd}$ to shoot by the PM, which inhibits photosynthetic activity and thus reduced the dry weight of maize plant. We have tried to find the role of bacterial produced organic acids in Cd concentration in roots and its translocation to shoot of maize. Positive correlation between organic acid contents in root exudates and Cd uptake in roots while the negative in case of shoots strengthen our hypothesis that organic acid production in the root exudates of maize remediate Cd in soil. Positive relationship of organic acids in root exudates and Cd uptake by roots has already been reported (Najeeb et al., 2011).

\section{Conclusions}

It is concluded that the application of organic acid producing MtPBR either alone or in combination with BGR ameliorate $\mathrm{Cd}$ contamination in soil through stabilization in maize roots and restrict translocation to shoot, which improve maize biomass and physiology. Therefore, it is conferred that this technique may be used to grow maize in $\mathrm{Cd}$ contaminated soil without compromising its biomass yield and quality. Further, the application of PM alone or in combination with BGR increased the Cd translocation to shoot. It is obvious from results that organic acid production in maize root exudates is responsible for stabilization of $\mathrm{Cd}$ in roots and translocation to shoot. The high production of organic acids in response to MtPBR + BGR increased whereas low production in response to PM decreased Cd concentration in root. 
Based on our findings, we can recommend combined application of MtPBR + BGR for improving maize biomass and phyto-management of $\mathrm{Cd}$ contaminated soil.

\section{Declarations}

\section{Funding}

The work is partially supported by the Higher Education Commission of Pakistan under SRGP grant.

\section{Authors contributions}

MT, IA, AD: writing - original draft preparation, methodology, investigation; UK, MA, MK: methodology, resources \& analysis; MS, MBK: writing- reviewing and editing; MT, IA: conceptualization, resources, supervision.

\section{Competing interests}

The authors declare that they have no known competing financial interests or personal relationships that could have appeared to influence the work reported in this paper.

\section{Ethics approval and consent to participate}

This study does not involve any humans or animals during experimentation, so it does not applicable in this study.

\section{Consent for publication}

This study does not contain data from any individual person, please state so it does not applicable in this section.

\section{Availability of data and materials}

The authors confirm that the data supporting the findings of this study are available within the article [and/or] its supplementary materials.

\section{References}

1. ABUBAKER J, RISBERG, K., \& PELL M (2012) Biogas residues as fertilizers - Effects on wheat growth and soil microbial activities. Appl Energy 99:126-134

2. AEBI H (1984) Catalase in vitro. Method Enzymol 105:121-126

3. AHMAD I., TAHIR M., DARAZ U., DITTA A., HUSSAIN M.B., KHAN Z.U.H. 2020. Responses and Tolerance of Cereal Crops to Metal and Metalloid Toxicity. In: Hasanuzzaman M (ed) Agronomic Crops. pp 235-264. Springer, Singapore 
4. AHMAD I, AKHTAR MJ, MEHMOOD S, AKHTER K, TAHIR M, SAEED MF, HUSSAIN MB, HUSSAIN S (2018) Combined application of compost and Bacillus sp. CIK-512 ameliorated the lead toxicity in radish by regulating the homeostasis of antioxidants and lead. Ecotoxicol Environ Saf 148:805-812

5. AHMAD I, AKHTAR MJ, ZAHIR ZA, MITTER B (2015) Organic amendments: Effects on cereals growth and cadmium remediation. Int J Environ Sci Technol 12:2919-2928

6. AHMAD I, AKHTAR MJ, ZAHIR ZA, NAVEED M, MITTER, B., \& SESSITSCH A (2014) Cadmium tolerant bacteria induce metal stress tolerance in cereals. Environ Sci Pollut Res 21:11054-11065

7. ANJUM SA, TANVEER M, HUSSAIN S et al (2016) Osmoregulation and antioxidant production in maize under combined cadmium and arsenic stress. Environ Sci Pollut Res 23:11864-11875. https://doi.org/10.1007/s11356-016-6382-1

8. ATSDR (2011) Agency for toxic substances and disease registry (ATSDR). The 2011 priority list of hazardous substances. http://www.atsdr.cdc.gov/SPL/index.html

9. Bali AS, Sidhu GPS, Kumar V (2020) Root exudates ameliorate cadmium tolerance in plants: A review. Environ Chem Lett 18:1243-1275

10. BEN-ASHER J, TSUYUKI I, BRAVDO BA, SAGIH M (2006) Irrigation of grapevines with saline water: I. Leaf area index, stomatal conductance, transpiration and photosynthesis. Agric Water Manag $83: 13-21$

11. Berni R, Luyckx M, Xu X, Legay S, Sergeant K, Hausman JF, Lutts S, Cai G, Guerriero G (2019) Reactive oxygen species and heavy metal stress in plants: impact on the cell wall and secondary metabolism. Environ Exp Bot 161:98-106

12. BI X, FENG X, YANG Y, LI X, SHIN, G.P., \& LI F et al (2009) Allocation and source attribution of lead and cadmium in maize (Zea mays L.) impacted by smelting emissions. Environ Pollut 157:834-839

13. Chen C, Li Z, Li S et al (2020) Effects of root exudates on the activation and remediation of cadmium ion in contaminated soils. Environ Sci Pollut Res 27:2926-2934. https://doi.org/10.1007/s11356019-07263-8

14. ESTEFAN G, SOMMER AND J. RYAN R (2013) Methods of Soil, Plant and Water Analysis: A Manual for the West Asia and North Africa Region, 3rd edition. ICARDA, Beirut, Lebanon

15. Georgiadou EC, Kowalska E, Patla K, Kulbat K, Smolinska B, Leszczynska J, Fotopoulos V (2018) Influence of heavy metals ( $\mathrm{Ni}, \mathrm{Cu}$, and $\mathrm{Zn}$ ) on nitro-oxidative stress responses, proteome regulation and allergen production in basil (Ocimum basilicum L.) plants. Front. Plant Sci 9:862. doi:10.3389/fpls.2018.00862

16. HASAN MM, NASHIR-UDDIN M, ARA-SHARMEEN I, ALHARBY HF, ALZAHRANI Y, HAKEEM KR, ZHANG $L$ (2019) Assisting phytoremediation of heavy metals using chemical amendments. Plants (Basel). 2019 Sep; 8(9): 295. doi: 10.3390/plants8090295

17. HEATH RL, PACKER L (1968) Photoperoxidation in isolated chloroplasts: I. Kinetics and 18. stoichiometry of fatty acid peroxidation. Arch. Biochem. Biophys. 125, 189-198 
19. KHURANA MPS, KANSAL BD (2014) Effect of farmyard manure on chemical fractionation of cadmium and its bioavailability to maize crop grown on sewage irrigated coarse textured soil. $\mathrm{J}$ Environ Biol 35:431-437

20. LATIF J, AHMAD AKHTAR,J, MAHMOOD-UR-REHMAN I, SHAH M, JAVAID GM,ZAMAN,Q, FAROOQI T, SHAKAR ZUR, M., SALEEM, A., \& RIZWAN M (2020) Unraveling the effects of cadmium on growth, physiology and associated health risks of leafy vegetables. Brazilian Journal of Botany. https://doi.org/10.1007/s40415-020-00653-0

21. LICHTENTHALER HK (1987) Chlorophylls and carotenoids: Pigments of photosynthetic biomembranes. Methods in Enzymology, Academic Press, 148, 350-382

22. LUX A, LACKOVIC A, STADEN VJ, LISKOVA D, KOHANOVA, J., \& MARTINKA M (2015) Cadmium translocation by contractile roots differs from that in regular, non- contractile roots. Ann Bot 115:1149-1154

23. MAYAK S, TIROSH AND B.R. GLICK T (2004) Plant growth-promoting bacteria that confer resistance to water stress in tomatoes and peppers. Plant Sci 166:525-530

24. MOREIRA H, FRANCO MARQUES,AP, RANGEL AR, A.O., \& CASTRO PM (2014) Phytomanagement of Cd-contaminated soils using maize (Zea mays L.) assisted by plant growth-promoting rhizobacteria. Environ Sci Pollut Res 21:9742-9753

25. MOSTOFA KM, LIU CQ, FENG X, YOSHIOKA T, VIONE D, PAN, X., \& WU F (2013) Complexation of dissolved organic matter with trace metal ions in natural waters. In: Mottaleb A, Mostofa MGK (eds), Photo-biogeochemistry of Organic Matter. 769-849

26. MOST P, PAPENBROCK, J (2015) Possible roles of plant sulfurtransferases in detoxification of cyanide, reactive oxygen species, selected heavy metals and arsenate. Molecules 20:1410-1423

27. NAJEEB U, ALI JILANI,G, SARWAR S, XU M, L., \& ZHOU W (2011) Insights into cadmium induced physiological and ultra-structural disorders in Juncus effusus $L$. and its remediation through exogenous citric acid. J Hazard Mater 186:565-574

28. NAKANO Y, ASADA K (1981) Hydrogen peroxide is scavenged by ascorbate-specific peroxidase in spinach chloroplast. Plant Cell Physiol 22(5):867-880

29. PERRIGUEY J, STERCKEMAN, T., \& MOREL JL (2008) Effect of rhizosphere and plant- related factors on the cadmium uptake by maize (Zea mays L.). Environ Exp Bot 63:333-341

30. PIRSELOVA B, LIBANTOVA KUNA,R, J., MORAVCIKOVA, J., \& MATUSIKOVA I (2011) Biochemical and physiological comparison of heavy metal-triggered defense responses in the monocot maize and dicot soybean roots. Mol Biol Reports 38:3437-3446

31. POTYSZ A, GRYBOS M, GUIBAUD KIERCZAK,J, FONDANECHE G, LENS P, P.N., \& VAN HULLEBUSCH, E.D (2017) Metal mobilization from metallurgical wastes by soil organic acids. Chemosphere 178, 197-211

32. PUERTAS-MEJIA MA, RUIZ-DIEZ B, FERNANDEZ-PASCUAL M (2010) Effect of cadmium ion excess over cell structure and functioning of Zea mays and Hordeum vulgare. Biochem Syst Ecol 38:285291 
33. PUTWATTANA N, KRUATRACHUE, M., KUMSOPA, A., \& POKETHITIYOOK P (2015) Evaluation of organic and inorganic amendments on maize growth and uptake of $\mathrm{Cd}$ and $\mathrm{Zn}$ from contaminated paddy soils. Int J Phytoremediat 17:165-174

34. RIZWAN M, ALI, S., \& QAYYUM MF et al (2016) Use of Maize (Zea mays L.) for phytomanagement of Cd-contaminated soils: a critical review. Environ Geochem Health 39:259-277. https://doi.org/10.1007/s10653-016-9826-0

35. SANGTHONG C, SETKIT, K., \& PRAPAGDEE B (2015) Improvement of cadmium phytoremediation after soil inoculation with a cadmium-resistant Micrococcus sp. Environ Sci Pollut Res. doi:10.1007/s11356-015-5318-5

36. SEREGIN IV, SHPIGUN LK, IVANOV VB (2004) Distribution and toxic Effects of cadmium and lead on maize roots. Russ J Plant Physl 51:525-533. https://doi.org/10.1023/B:RUPP.0000035747.42399.84

37. SETHI S, GUPTA S (2015) Responses of soil enzymes to different heavy metals. Biolife 3(1):147153

38. SHAHID M, ECHEVARRIA AUSTRUY,A, ARSHAD G, M., SANAULLAH, M., ASLAM, M., NADEEM, M., NASIM, W., \& DUMAT C (2014) EDTA-enhanced phytoremediation of heavy metals: a review. Soil Sediment Contam 23:389-416

39. SHUMBA A, NYAMASOKA MARUMBI,R, NYAMUGAFATA B, P., NYAMANGARA, J., \& MADYIWA S (2014) Mineralisation of organic fertilizers used by urban farmers in Harare and their effects on maize (Zea mays L.) biomass production and uptake of nutrients and heavy metals. S Afr J Plant Soil 31:93-100

40. STEEL RGD, TORRIE AND D.A. DEEKEY JH (1997) Principles and Procedures of Statistics: A Biometrical Approach, 3rd edition, pp: 400-428. McGraw Hill Book, New York, USA

41. TAHIR M, ASIF NAEEM M, SHAHID M, KHALID U, UMER FAROOQ AB, AHMAD N, ARSHAD AHMAD,I, M. \& WAQAR A (2020) Inoculation of pqqE gene inhabiting Pantoea and Pseudomonas strains improve the growth and grain yield of wheat with a reduced amount of chemical fertilizer. J Appl Microbiol. doi:10.1111/jam.14630

42. TAHIR M, MIRZA MS, HAMEED S, DIMITROV MR, SMIDT H (2015) Cultivation-based and molecular assessment of bacterial diversity in the rhizo sheath of wheat under different crop rotations. PLoS ONE 10:e0130030

43. TAHIR M, MIRZA MS, ZAHEER A, DIMITROV MR, SMIDT H, HAMEED S (2013) Isolation and identification of phosphate solubilizer' Azospirillum, Bacillus and Enterobacter strains by 16SrRNA sequence analysis and their effect on growth of wheat (Triticum aestivum L.). Aust. J. Crop Sci. 7 , $1284-1292$

44. TAHIR M, IJAZ KHALID,U, SHAH M, NAEEM GM, SHAHID MA, M., MAHMOOD, K., AHMAD, N., \& KAREEM F (2018) Combined application of bio-organic phosphate and phosphorus solubilizing bacteria (Bacillus strain MWT 14) improve the performance of bread wheat with low fertilizer input under an arid climate. Braz J Microbiol 49(1):15-24 
45. XU W, LU G, DANG Z, LIAO C, CHEN, Q., \& YI X (2013) Uptake and distribution of Cd in sweet maize grown on contaminated soils: A field-scale study. Bioinorg Chem Appl. doi:10.1155/2013/959764

\section{Figures}
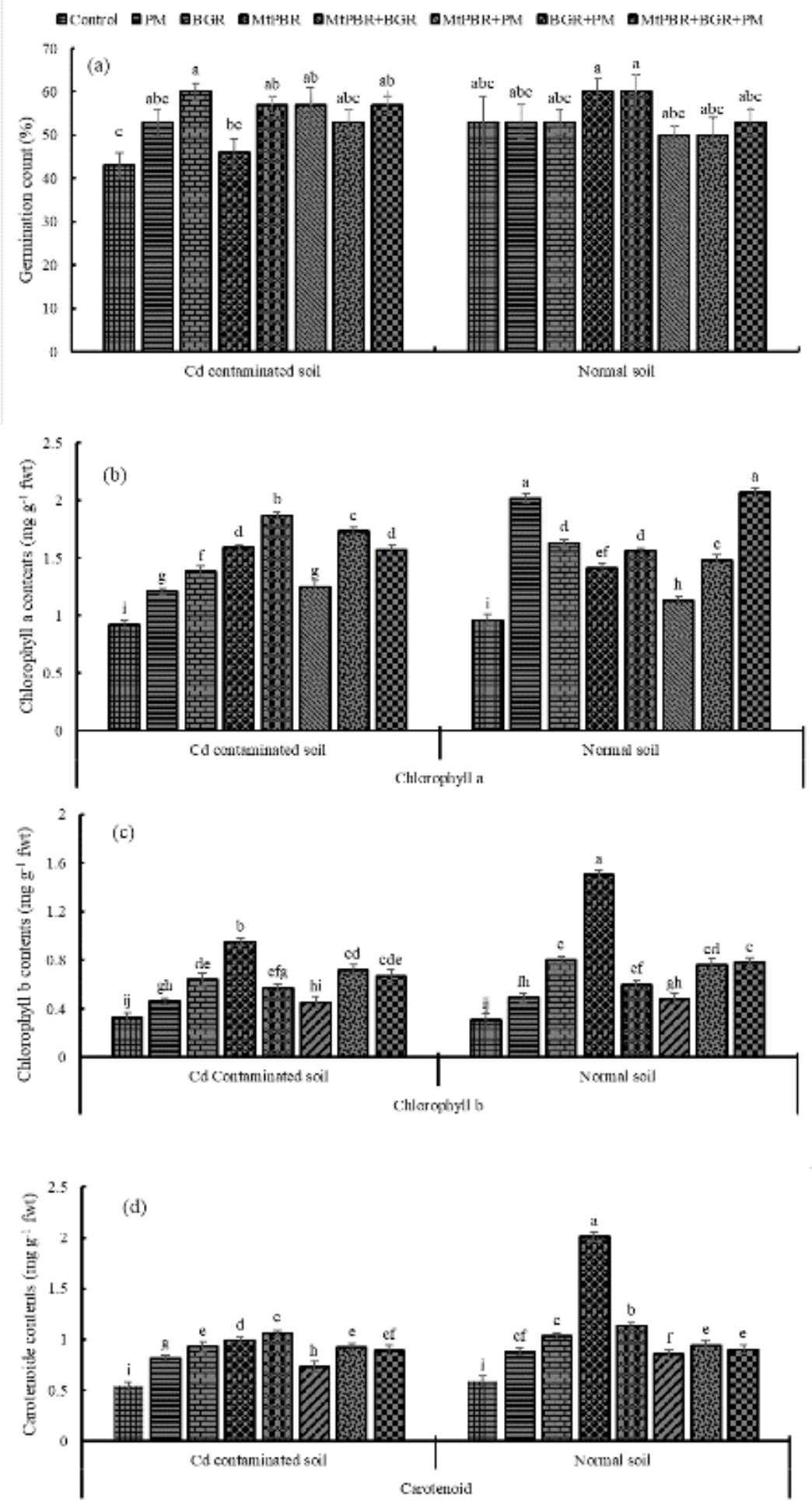

Figure 1 
Effect of Pantoea sp. strain WP-5 and organic amendments on maize (a) seed germination, (b) chlorophyll a, (c) chlorophyll b and (d) carotenoids contents in normal and Cd contaminated soils. Values are the means $( \pm S E)$ of five replicates $(n=5)$. Different letters on bars show statistically significant difference among the treatments $(P \leq 0.05)$ while the values sharing the same letter are statistically nonsignificant following least significant difference (LSD) test.
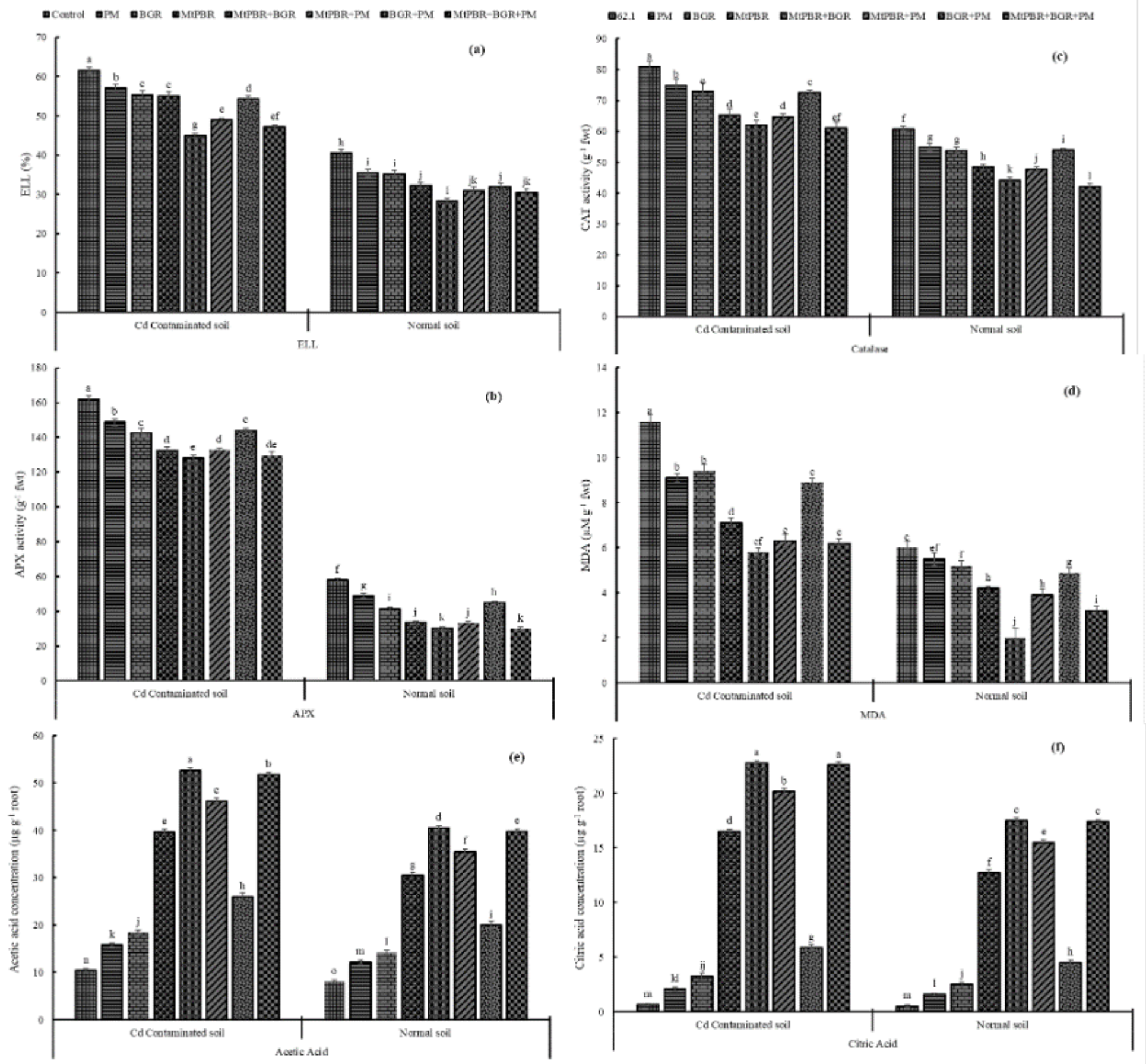

Figure 2

Effect of Pantoea sp. strain WP-5 and organic amendments on maize (a) electrolyte leakage (ELL), (b) ascorbate peroxidase (APX), (c) catalase (CAT), (d) malondialdehyde (MDA) contents, (e) acetic acid and (f) citric acid concentration in normal and Cd contaminated soils. Values are the means ( \pm SE) of five 
replicates $(n=5)$. Different letters on bars show statistically significant difference among the treatments $(P \leq 0.05)$ while the values sharing the same letter are statistically non-significant following least significant difference (LSD) test.

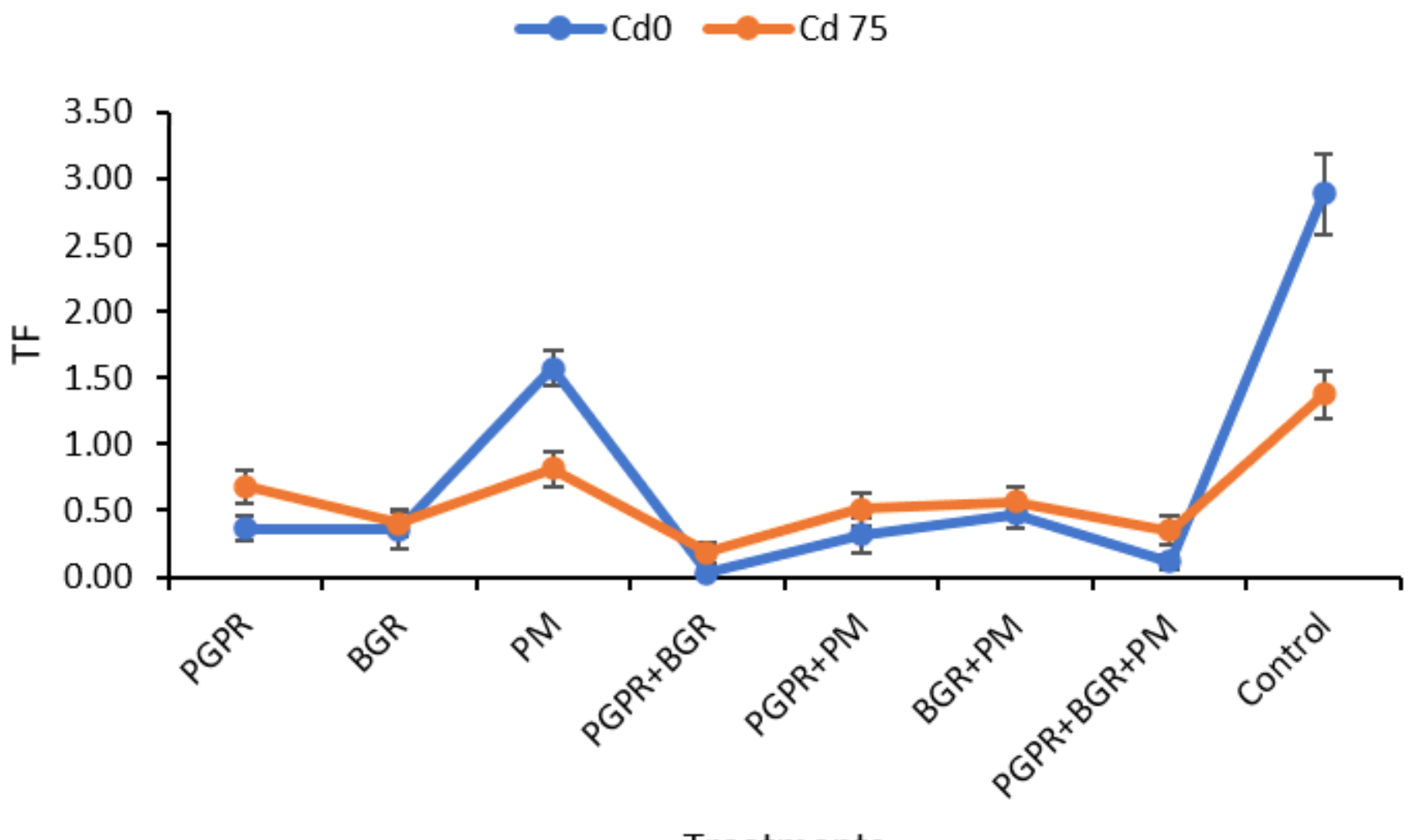

Treatments

\section{Figure 3}

Effect of Pantoea sp. strain WP-5 and organic amendments on translocation factor from root to shoot in maize. Values are the means $( \pm S E)$ of five replicates $(n=5)$. 

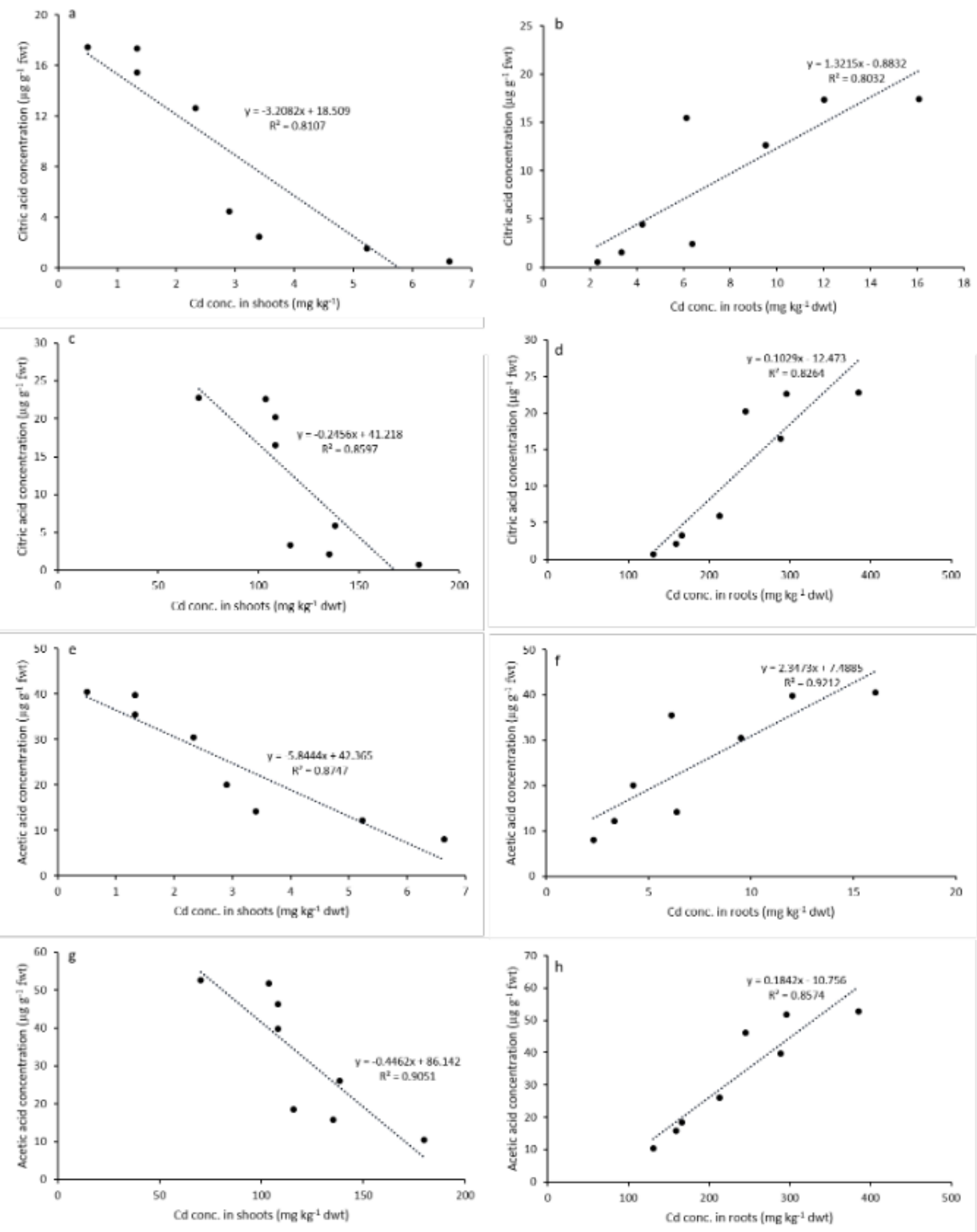

\section{Figure 4}

Linear regression analysis to show the relationship of organic acids production with $\mathrm{Cd}$ concentrations in shoots and roots of maize in normal $(a, b, e, f)$ and Cd contaminated soils $(c, d, g, h)$ at $P<0.05$. 